\title{
from 'Cutting Re / Marks'
}

\author{
Betsy Warland
}

\section{Re / marques tranchantes}

Que se passe-t-il quand on nous opère, que l'on nous enlève un 'morceau' de nous-même? Pouvons-nous signer de la même façon notre nom? Notre nom est-il encore la représentation de notre moi? Ou est-il amputé de quelque chose? Durant leur vie, les femmes subissent plusieurs amputations (chirurgicales et morales). Les dommages encourus marquent le corps des femmes. Le corps parle et signe en lieu et place de leur non-dit et de leur douleureux silence.

we think in images. we remember in images. repressed images reassert themselves upon us again and again without our recognition - until we cease to leave them out; cut them out. until we tell the story.

\section{the body says 'write this'}

we've never met. we're talking on the phone. this stranger's voice says to me 'i hate the thought of them cutting me up - invading me like that.' not cut but invade. rape, rep-, to seize; rapid, surreptitious. she is feeling what i felt too; what i've heard so many other women speak of. being entered against our wills, even though we yield, 'she must have asked for it.'

surreptitious, sub, under, secretly + rapere, to seize anesthetic, an-, without + aisthetos, perceptible

do men feel this way? i hardly know of any men who have had major surgery. my parents seem the classic stereotypes: my mother having gallbladder surgery and a hysterectomy; my father having a heart attack and then a stroke. are there comparative statistics on this? i 
know women have surgery much more frequently. the forced entry. the flowing of blood. surgery. the breaking in of a virgin. the violent rape. all routine. all very familiar. the way things are.

sitting with my mother over lunch, my father in hospital with a stroke. she telling me all the major and minor surgeries she's had. a long list unravelling over the years, over the dreary food. the dramas of her body. saw then how she has always believed something is wrong with her: wrong from the beginning. her unexplained blackouts as a child. she has been trying to diagnose, dia-apart + gignoskein, to perceive what is wrong with her her whole life.

who is perceiving and who is apart? the disassociating of ourselves from our own dis-eases. all the cutting into and cutting out makes no difference. all these sacrificial organ deaths yet no peace comes. there is no such thing as 'routine surgery.' a part cut out is apart from your body forever. the dead ovary, the dead gallbladder like phantom limbs insist on living again; will not accept unmarked graves. i inscribe them here. they have gone before me and lived my death. they reincarnate on this page.

the stone in me was like myself: a solitary planet. it looks like a planet. $i$ know this stone is the sadness $i$ buried deep ever since $i$ was old enough to know how to do so. the sadness of alienation (ab-norm); my spirit always too large; $m y$ desires always too intense-disquieting for those i was intimate with. Daphne is the first lover who meets me equally. no happenstance that the stone insisted on leaving: breaking its orbit. that sensation of inadvertently finding evidence of my childknowing: the 'odd marbles' in my grandmother's drawer as she lay in her paralyzed sleep in the next room. my astonishment when $i$ was told what they were. the yellow and brown swirl-coloured marbles. a small jar full of them. enough to fill my 7 or 8 year-old hand. they felt like the sum of words never said. the hardened secrets of her private melancholy, gall yellow, gold, gleam, glitter, bright, glad, glow. the sparkling flecks on the ends of my stone. the stone cinder-black. the flecks. light forced to turn back in on itself? 
hospital, ghos-ti-, guest, host, hostile: always on my guard against my host's hostility. only a facial expression away. i am courteous but $i$ keep to myself as much as possible. stripped of almost everything $-i$ am too vulnerable to other people's energies. $i$ am getting ready to 'go under' (Persephone and the pomegranate seed); be cut open. all my concentration is required to prepare myself. i need to be ready for anything; at least the possibility of. for anything is possible. that strange saying 'if something happens to me ...' something is always happening to us: this isn't something. this is something else.

the night before my surgery both Daphne and i feel peaceful. the 'prep lady' (far from being preppy) comes in to shave my mound. she shaved around my belly button two days ago before my laparoscopy. $i^{\prime} d$ noticed her nonchalance and humour then. for the first time since i've been here i make an open comment to her when she finishes: 'you have a nice spirit.' she smiles and says 'oh, people aren't always what they seem you know. $i$ 've been crying for my husband for the last four years. every night. i just can't seem to stop. he died four years ago. i found him on the floor like that. he didn't look happy that way you know. it would have helped if $i$ hadn't come home and found him that way. he was a pharmacist; scottish. the nicest man. we were so happy together. and the cat. he loved that cat. it sat on his lap for hours and he combed its fur just a certain way. the cat wanted to die for weeks after. it would go outside and bury its head in the grass for hours. what do you do? i've cried every night and i can't seem to stop - and then my son. his wife lost her father just a month ago. two weeks before christmas and she was so close to him. he' $\mathrm{d}$ had 8 heart attacks, and a half a year ago-open heart surgery for 18 hours ... but he died anyway. and she's just like me: can't stop crying. wakes up every morning that way. can hardly get to work. and my son - he's getting tired of it. says 'what am i going to do with her?' i tell him he's gotta be patient with her, she loved her dad so much. but he says she's got to shape up-you can't go on crying forever. i guess it's good i've been alone all those nights. it hurts to be but at least i can cry and not worry. i wonder if $i^{\prime} l l$ ever stop sometimes. do you have 'Faith?' some people say that it helps. i don't know ... you know it was such a shock. we were so happy together. he was the nicest man. it was my second marriage and i was so much happier with him you know. my son says we shouldn't go on like this but i know just how she feels-his wife-what 
are you supposed to do?' it poured out for twenty minutes and then she left with her thick mascara-blue eyelids and lipstick smile. her grief: the air in the room. so thick. our lungs taking short little lurches at it. we didn't want to take it in, breathed as shallow as possible. there was no time left. 'visiting hours are over' had been announced several minutes ago and now the flat-toned nun was smoothing out the grey blanket of her evening prayer over the entire hospital. we had to kiss and hold each other quickly before a nurse turned the handle. we had to refind our own peace over the next hours, before we could each fall asleep. in our separate beds. in our separate souls.

the next morning $\mathrm{i}$ stood. waited at the guests' lounge window. watched as far as the Burrard Street bridge for Daphne's faded red toyota. coloured metal streaming intently through concrete arteries. i needed to see her out there. moving midst it and toward me. i stood at that fourth floor window and when i saw that red, i vowed not to do this again. i would find another way.

i've stayed away from this 'piece' for a few days. stayed away from these feelings; needed a 'break' but my sleep-self has called me back. insisted i re-turn. roll over in the night / sharp pain in my diaphragm, dia-, completely + phrassein, to enclose. day-self suddenly face to face with night-self, forcing me to acknowledge the dream $i$ just had. sitting up. trying to breathe. ease the pain. Daphne's awake now. rubbing my back. i tell her the dream: 'i was dreaming about 'the line' the long prose-poetry line. my lines - the ones i've been writing lately. all the lines were forming into bars around me / enclosing me / constructing a cage. $i$ felt so panicky: $i$ didn't have much time - $i$ had to find a way out or i' $d$ be caught behind these bars. trapped for ...' writing is a constructing of the cage of our own particular / peculiar reality. as i write line-bars gradually build their way down the open page. the dreaded Pan in the woods. the woods at night the tree-trunk dark cage. trunk, ter-, pass through, overcome: that moment when we knock the tower of blocks over, when things we've constructed threaten to clone us. self-survival? not destructiveness? we must find our way out. overcome our own trees, deru, truths. see the trees for the forest. the line must never stop rewrighting itself, as trees recede and re-seed. 
Hillman: 'By conceiving symptoms as sacrifice, they take on new meanings and receive soul.' the symptom not 'apart' or a 'part' or a 'piece': symptom, sun-, together + peptein, to fall. all the pieces falling into place. 'Quantum theory thus reveals a basic oneness of the universe. It shows that we cannot decompose the world into independently existing smallest units.' and if we are unaware that this is not 'routine surgery' but sacrifice - what happens then?

limb. the losing of a limb; not only an arm or leg (is that what it cost you?) but any part of us; any branch any root. limb / limbo.

bitter, to split, bite, bait, fission.

sitting in the waiting room. i recognize the woman sitting across from me; we have a mutual friend in common. after 'hello' there's the inevitable 'how have you been?' her face becomes in / tense as i tell her that i've recently had surgery. she asks me several questions about it. no deflective 'oh' and quickly moving on to another topic. so $i$ ask her if she's ever had surgery. her face gives me the answer before her words: 'Yes, several years ago.... I'll always be bitter about it.'

now, when writing this frightens me; when ithink perhaps i should be writing 'something' else; that maybe i' $m$ simply being self-indulgent - $-i$ think of her limbo. $i$ think of the great knot of her face.

being wheeled down to OR. life or ... entering the state of or, Middle English, contraction of other. going to the place Of Other. Daphne walking alongside, holding the chrome side of the Patient Lift (my mother's saying 'it gave me such a lift'). lift before the fall.

at the double doors we say goodbye. i look in her eyes: 'siempre.' tears. blurr of swinging doors and i'm wheeled into the Holding Room. this is as alone as it gets. on the brink of ... the holding of your dear-one's hand - denied. yet, i choose to think of this name as comforting - Holding Room - and feel myself gathered up by a greater, disembodied tenderness. the nurse comes up and asks my name and if $i$ know what type of surgery $i$ am having. she gives me a paper cap for my head, which has a bizarre similarity to a party hat, and asks me if i'm warm enough. she leaves, placing a large clipboard on top of my 
legs: my storyboard. there are three others lined up parallel to me in the dimly lit room: i pray for each one. i've intentionally not accepted sleeping pills or tranquillizers and seem to be more alert than the others. $i$ wanted the calming to come from within my own body and soul, and it has. we are all going in for different types of surgery ( $i$ hear the nurse speaking to each of them). i wonder how Daphne is doing: send her my love. then remember a friend of mine telling of how she was lined up with seven other women, out in a hallway, who were all scheduled for mastectomies. i rehear her indignity at the sense of a conveyor belt lopping off their breasts: 'It was like a goddammed parking lot!'

in my mind i talk gently to my ovaries and uterus. with my hand on my abdomen, i prepare my body for the invasion, assuring it, urging it to not resist, struggle against, but rather flow with the presence of these others soon to enter me.

soon my skin will be rendered meaningless.

limbo, in, on + limbu, border.

soon $\mathrm{i}$ am going to the place of Other; my consciousness will be taken from me; my memory intercepted. only my tissue will voice where we have been: pain its only syllable. memory a cry or moan.

'Betsy Warland?'

'yes.'

'I've come to take you to OR.'

'OK.'

down the cool hall i think of Daphne. wonder if it isn't harder to wait.

'We're going to room 9.' 


\section{from 'Cutting Re/Marks' · 57}

zenith number: death; enlightenment; fruition....

it surprised me the first time - how empty these rooms are. how narrow and cold the surface of the operating table is. two nurses are in the corner counting out loud and in unison the sponges and instruments [two and two makes four; four and four makes eight ... it never stops] the anesthesiologist comes up, introduces himself and i check with him about the type of anesthesia i've requested. the resident doctor $i$ spoke with yesterday comes up and says 'hi.' the anesthesiologist asks one of the nurses to call on the intercom to see if Dr. Simmons is ready for surgery: 'Yes, she's on her way.' the one nurse attaching the monitor disks on my torso chats about how expensive they've become. except for the huge disk light above me (which is not yet on) and the sound of the nurses counting, $i$ can see no instruments or equipment: no evidence of what's about to happen. only people. later, i saw a series of photographs in a book which recorded each state of the elaborate 'draping' the patient before surgery. drap, der-. to split, peel, flay, derma, epidermis, trap. the clock on the wall is at three minnutes to noon. the anesthesiologist says 'Betsy, I'm going to give you your first injection now. It will come through the intravenous and you will feel your eyes rolling back for a few moments. Are you ready?' 'Yes.' it hits quickly. my eyes have a horrible fluttering sensation, futile fluttering against glass my whole body in a slow motion backflip deep-pit-fall ... the next thing i know my eyes are opening to a clock on the Recovery Room wall. it's three fifteen.

i immediately scan my body to assess how $i$ am: can tell i've come through surgery all right. a nurse at my side now asks me if $i$ know my name. to her, this question is recovery procedure, to me it is a sign of how radical these past three hours have been. how they've altered me to the core yet all $i$ can say is my name. and i'm grateful i can: it's perhaps the last thread that holds us here. the nurse is now taking my pulse; blood pressure; asking me if $i$ feel ok. my body is shuddering inside. she brings me a warm blanket which feels reassuring. i become aware of the other patients in the room. the drugs are dulling my pain sufficiently and this particular pain is more familiar this time. i remember being so relieved after $i$ woke up from my gallbladder surgery: the pain was not nearly as excruciating as the attacks had beenwhich no pain killers could relieve. why 'killers?' when confronted 
with something they don't like; feel fearful of - violence seems to always be The Fathers' first instinct and institutionalized response.

as $\mathrm{i}$ lie here now, $\mathrm{i}$ become more aware that 'something' has moved through me; 'something' that had total authority over me which altered my body, my spirit ... everything feels shifted inside. everything seems to be trembling with shock. i lie very still and say a prayer; know $i$ have been held within the circle of light. the anesthetic is the heaviest i've had. it has taken me near enough to the threshold of death, near enough that my soul had begun to protectively move a step before me. like incest - the emotions are all here but the memories are repressed. it is now $4 o^{\prime}$ clock.

'Betsy, we're going to send you back to your room now,'

i smile with the thought of seeing Daphne and quietly holding her hand. that connection - my arm, hand to her hand, arm: the umbilical cord birthing me back into this life. she's standing outside my room door when i arrive. smiles 'hi love.' 
from 'Cutting Re/Marks' · 59

'i've seen her face 2 times now just back from surgery, returned to consciousness, \& each time it has seemed so intensely pure to me, spiritual, as if her flesh has somehow lost its materiality - her spirit there so gravely - a grave stillness in her face then as if cleansed of everything but pure being - conscious of just being not of wanting anything, or striving for something, just there and only there - fragile, yes, vulnerable because so self-revealed, but enduring, not strong in the way we usually think of strength (assertive) but in presence of simply continuing even within fragility - feeling very close to her own fate (don't know what other word to use - but it is that sense of shape not her usual identity (personality) but very much hers - where death defines her) $\mathcal{E}$ she looks then so completely $\mathcal{E}$ purely herself-it is as if $i$ see her again for the first time, fall in love again for the first time, seeing her so clear of everything but her death, toward which she is moving $\&$ which also allows her to be who she is."*

* Excerpt from an unpublished journal by Daphne Marlatt. 


\section{$60 \cdot$ Tessera}

twice $i$ have had surgery. twice $i$ have had my memories of this profound experience 'seized.' though i heard every word, every sound, though my tissue felt every violation - those hours of broken boundaries within that clean room on that cold-narrow table are a blank space in my conscious mind. an empty screen on my black monitor. not even an A prompt

only a $\operatorname{com}(m) a$, koptein, to cut

('what they don't know won't hurt them')

this is the cut that hurts most

this is where the damage is done

\section{$\boldsymbol{I}$}

and this is where the damage is held

condensed on this page

like a tear in limbo

repressed images reassert themselves upon us over and over again until we recognize them; until we cease to leave them out; cut them out.

until we wake up from the $\operatorname{com}(\mathrm{m}) \mathrm{a}$

the woman who went from doctor to doctor, trying to find a diagnosis for the gnawing pain in her thigh. no relief. no accurate explanation. the pain relentless. finally, in desperation ('it's all in your head') she tried hypnosis (stop smoking after one session?) and there it was. the memory. intact. an intern leaning against her as he observed a surgery which she had undergone. leaning against her. making disparaging remarks about her body. the insult the injury absorbed into her tissue her cells at the point of contact: his arm on her thigh. her pain the words she was denied. after remembering - the pain vanished. she had needed to know her story; she had needed to speak her anger; she had needed to have herself back again. her body, in her own terms. intact, in-, not + tactus, to touch. 
Louky Bersianik's belief that woman is a victim of amnesia - which is our genderization. our brainwashing so normalized that we are barely aware of it. often our only tangible, tangibilis, to touch sign is a gnawing, inexplicable pain. kwei-, penalty, penal, pine, punish. the penalty of our gender: the pain we catch a glimpse of in one another's eyes?

the body says write this

i told Daphne about the seagull two days later. i had decided not to tell her-didn't want to worry her. it seemed a private omen: one i was to hold quietly to myself at the time.

at four o'clock, on the day before my surgery, i was lying in bed. no one else was around. suddenly i heard a wailing cry. outside the window $i$ saw a seagull alone on the northeast corner of the hospital roof. it was the most poignant cry: it wailed out four times into the southwest still-grey day. $i$ felt convinced that someone had died and the gull was releasing their spirit skyward. an hour later $i$ heard a baby had died in its birthing 'at four o' clock this afternoon' it was the only death $i$ heard of in the nine days i was there (death a taboo). the next morning a gull (that gull?) landed on my window ledge. Daphneand $i$ were astonished as this hadn't happened before. it was so close. looked intent and straight at us as we said 'hi!' we were struck by its beauty but i watched in silence. it was here for me, there was no doubt in my mind. though this frightened me, $i$ felt more moved by its purity. it was a magnificient gull with intense, sweet-bronze eyes and sun-white breast. $\mathrm{i}$ knew it was waiting for a response from me. i addressed it with my inner voice.

'why are you here?'

'i've come to see if you're ready.'

'no, i'm not... i have work to do; work which i've committed my spirit to. you are beautiful, $\mathrm{i}$ would be honoured to have my spirit released by you, but it's not my time. go away in peace.' and it flew away immediately. 


\section{$62 \cdot$ Tessera}

for several days after surgery that horrible broken feeling every time you sit, stand, or roll over - your insides avalanching. the fear at first that if you move the wrong way or too much or too fast everything will come undone. the unbrokens' illusion of their bodies' indivisibility. their bodies as shields invulnerable against ... shields, to cut, scalpel. 'let's play Doctor.' sugar daddies / surgery daddies. the knife has two edges.

the boundary of my skin has been broken. cut open. it has known long moments of meaninglessness. body parts of hundreds of thousands of us are collected each day and burned to what god?

the skin reunites like two lips. tight lipped: 'my lips are sealed.' out of these scar-mouths our stories can be told - but this time, we must open them ourselves. 